\title{
Right target, wrong mechanism? Agricultural modernization and poverty reduction in Uganda
}

DOI:

10.1016/j.worlddev.2004.09.008

Link to publication record in Manchester Research Explorer

\section{Citation for published version (APA):}

Bahiigwa, G., Rigby, D., \& Woodhouse, P. (2005). Right target, wrong mechanism? Agricultural modernization and poverty reduction in Uganda. World Development, 33(3), 481-496. https://doi.org/10.1016/j.worlddev.2004.09.008

\section{Published in:}

World Development

\section{Citing this paper}

Please note that where the full-text provided on Manchester Research Explorer is the Author Accepted Manuscript or Proof version this may differ from the final Published version. If citing, it is advised that you check and use the publisher's definitive version.

\section{General rights}

Copyright and moral rights for the publications made accessible in the Research Explorer are retained by the authors and/or other copyright owners and it is a condition of accessing publications that users recognise and abide by the legal requirements associated with these rights.

\section{Takedown policy}

If you believe that this document breaches copyright please refer to the University of Manchester's Takedown Procedures [http://man.ac.uk/04Y6Bo] or contact uml.scholarlycommunications@manchester.ac.uk providing relevant details, so we can investigate your claim.

\section{OPEN ACCESS}


Right Target, Wrong Mechanism?

Agricultural Modernization and Poverty Reduction in Uganda

Author-accepted manuscript for publication in World Development 33 (3) (March, 2005)

Godfrey Bahiigwa

Economic Policy Research Centre,

PO Box 7841,

Kampala, Uganda.

bahiigwa@eprc.or.ug

Tel. +256 $41541023 / 4$

Fax: +25641541022

Dan Rigby,

School of Economic Studies,

University of Manchester,

Dover Street,

Manchester

M13 UK

dan.rigby@man.ac.uk

Phone: +441612754808

Fax: +441612754812

Philip Woodhouse,

Institute for Development Policy and Management,

University of Manchester,

Harold Hankins Building,

Precinct Centre,

Oxford Road,

Manchester,

M13 9GH UK.

phil.woodhouse@man.ac.uk

Phone: +44 1612752801

Fax: +44 1612738829 


\section{Right Target, Wrong Mechanism? Agricultural Modernization and Poverty Reduction in Uganda}

\section{SUMMARY}

A period of rapid economic growth during the 1990s in Uganda was accompanied by a reduction in rural poverty, as measured by surveys of household consumption. The Ugandan government's Poverty Eradication Action Plan (PEAP) aims to reduce poverty so that it affects no more than 10 percent of the population by 2017. The strategy to achieve this, the Plan for Modernization of Agriculture (PMA), seeks to promote cross-sectoral investment to improve agricultural productivity and increase marketed agricultural output from poorer farming households. This paper examines both the target of the PMA, and its primary mechanism: the decentralized delivery of investment and services to farming households. The paper draws on field data on income structure of farming households and early findings from monitoring the implementation of the PMA. It argues that, while there appear few, if any, better choices of 'target' for the PMA than that of improving the incomes of the rural poor through increased agricultural productivity, the emphasis on decentralization as a mechanism for poverty reduction is misplaced in the current political context of Uganda. The paper considers what alternative mechanisms might be adopted to achieve the PMA target of reducing rural poverty.

Key words - Africa; Uganda; livelihoods; decentralization; agriculture; 


\section{ACKNOWLEDGEMENT}

This work was funded by the Department for International Development of the United Kingdom (grant R7076). However, the findings, interpretations and conclusions expressed in this paper are entirely those of the authors and should not be attributed to Department for International Development, which does not guarantee their accuracy and can accept no responsibility for any consequences of their use. 


\section{Right Target, Wrong Mechanism? Agricultural Modernization and Poverty Reduction in Uganda}

\section{INTRODUCTION}

In debates regarding the effects of structural adjustment, privatization, de-regulation and increasing the openness of African economies to international trade, Uganda has become something of a cause célèbre. In a recent examination of Uganda's economic development since 1986, Dijkstra and van Donge comment that "Uganda is often seen as an African show case for the beneficial effects of structural adjustment. High growth rates have been combined with a high degree of 'ownership' of the reforms" (2001: 841). Others have drawn more pessimistic conclusions, however, notably that structural weaknesses in the Ugandan economy persist and that agricultural supply response to reforms has been weak (Belshaw et al.,1999).

The purpose of this paper is not to re-visit this debate regarding the causes and effects of reform and economic change, but rather to assess the current phase of the Ugandan government's economic strategy, specifically the Plan for Modernization of Agriculture (PMA) and its role within the Poverty Eradication Action Plan (PEAP). These programs are closely linked, backed by large donor funding and regarded as critical for the future of the economy at both macro scale, in terms of growth and exports, and at the micro scale of rural development and poverty alleviation.

Uganda's status as African 'show case' and the linkage of the PEAP and PMA with a set of measures implemented throughout Africa within Structural Adjustment Programmes (SAPs), such as decentralization, privatization and export promotion, mean that the impact of PEAP and PMA will have significance beyond the borders of Uganda. This paper draws on field data on income structure of farming households and early findings from monitoring the implementation of the PMA. It asks firstly whether the PMA has identified the 'right target' in agricultural modernization to achieve a reduction in rural poverty, and, secondly, if the programs being implemented represent the most effective mechanisms for achieving that goal.

\section{THE PMA IN THE UGANDAN CONTEXT: TRENDS IN POVERTY AND AGRICULTURE.}

\section{(a) Poverty trends}

Poverty trends in Uganda have been monitored for more than a decade using national household consumption surveys (Appleton, 2001a; 2001b; Balihuta and Sen, 2001; UBOS, 2003). Appleton's (2001a, 2001b) analyses of poverty trends during the 1990s concluded that the number of rural households below the poverty line in Uganda fell from 69 percent in 1992 to 49 percent in 1997/98 and to 39 percent in 1999/00. Balihuta and Sen comment that:

“one of the key features of Uganda's economic performance in the 1990s has been the sharp and sustained fall in rural poverty...much of the decrease in rural poverty has occurred in the 1997-2000 period- that is, after the liberalization of the agricultural sector in the 1990s" (2001:4).

However, the most recent survey, in 2002-3, indicates an annualized growth rate of household consumption of only 0.9 percent in Uganda for the three-year period 1999-2000 to 2002-3. This represents "a dramatic deceleration compared to the rates implied by the household 
surveys in the 1990s" (UBOS, 2003: 43), and is reflected in a reversal of the downward trend in rural poverty indicators over the past decade (Table 1). Further, rising Gini coefficient values imply that the increase in rural poverty since 2000 has been accompanied by a continuation of a trend of increasing inequality within rural areas since 1997. Data summarized in Table 2 show rural consumption levels are a half to a third of those of urban households, but all urban and most rural households recorded a drop in consumption between 2000 and 2003. It is perhaps significant that the exception was the highest decile of rural households, who registered a 5 percent increase in consumption expenditure.

[TABLE 1 ABOUT HERE]

[TABLE 2 ABOUT HERE]

\section{(b) The Plan for Modernization of Agriculture}

The Ugandan Government's Poverty Eradication Action Plan (PEAP) was established in 1997 as its policy framework for fighting poverty for the period 1997-2017, with an overall goal to reduce 'absolute poverty' to less than 10\% of the population by 2017 (MFPED, 2000; MFPED, 2001a). Internationally accepted as Uganda's Poverty Reduction Strategy, the PEAP promotes multi-sectoral activities towards four principal goals: (i) a framework for economic growth and transformation; (ii) good governance and security; (iii) an increased ability among the poor to raise their incomes; and (iv) an improved quality of life for the poor.

The PEAP activities focus mainly on primary health care, rural feeder roads, education, and water supply. With the publication of the Plan for Modernization of Agriculture (PMA), in 2000, PEAP activities were extended to include the promotion of commercialization of agriculture (MAAIF and MFPED, 2000). The funding of PEAP activities is linked to macrobudget planning through a Medium Term Expenditure Framework (MTEF) which defines the overall budget constraint. The operation of PEAP brings together two strands of reform: decentralization of governance; and 'pro-poor' expenditure of funds made available under the Heavily Indebted Poor Country (HIPC) debt-relief programme.

The PEAP was revised in 2000 on the basis of, among other things, the Uganda Participatory Poverty Assessment Project (UPPAP, 2000), and the first Poverty Status Report (MFPED, 2001b). These argued that, although the contribution of agriculture to Uganda's GDP had fallen little (down from $45.7 \%$ in 1996 to $41.5 \%$ in 2000), and the overwhelming majority of the population (85.8 percent in 2000) lived in rural areas, growth during the 1990s had been 'urban biased', resulting in a $42 \%$ increase in real consumption per adult equivalent in urban areas as compared to $15 \%$ in rural areas. As a consequence, $96 \%$ of the poor were located in rural areas in 2000, an increase from 93\% in 1992 (MFPED, 2001b; EPRC, 2002), contributing to the perception that poverty was predominantly, if not exclusively, a rural problem in Uganda.

The logic behind the PEAP and PMA is that a policy to reduce poverty must have a convincing strategy towards the rural economy, and, in a rural economy based essentially on agriculture, the key to poverty eradication is 'agricultural modernization', envisaged as increased productivity alongside a more commercial orientation among farmers. This is reflected in the PMA's mission of "eradicating poverty by transforming subsistence agriculture to commercial agriculture" (MAAIF and MFPED, 2000:27).

The main objectives of the PMA are identified as (i) increase incomes and improve the quality of life of poor subsistence farmers through increased agricultural productivity and increased share of marketed production, (ii) improve household food security through the market rather than emphasizing self-sufficiency, (iii) provide gainful employment through the secondary 
benefits of PMA implementation such as agro-processing factories and services, and (iv) promote sustainable use and management of natural resources by developing a land use and management policy and promotion of environmentally friendly technologies (MAAIF and MFPED, 2000).

In order to achieve these objectives, seven intervention areas (often referred to as 'pillars') were identified, including research and technology development, agricultural advisory services, rural finance, agro-processing and marketing, agricultural education, supportive infrastructure, and sustainable natural resource use and management. An additional intervention is the Non-Sectoral Conditional Grant (NSCG) to local governments to implement rural poverty reduction programs, the role of which is discussed in Section 4.

PMA interventions cover many of the same areas of support that governments have traditionally applied to agriculture. However, it is argued that the approach to implementation is different because it is more 'demand-driven'. Agricultural research is expected to shift more resources toward research that addresses the needs of poorer farmers. Agricultural Research Development Centers (ARDCs), sited to reflect the range of agro-ecological zones, have been created to serve the specific interests of farmers where they are located. Similarly, agricultural extension has been renamed the national agricultural advisory service (NAADS), with the change of name intended to underline a two-way exchange between the farmer and the service provider. A perhaps more immediate effect is the simultaneous shift towards private service provision. The principal role of NAADS is to facilitate formation of farmer groups at the local level, and farmer forums at sub-county, district and national levels. Farmers groups are expected to articulate their needs and purchase technical services from private service providers, paid for by the public sector through the decentralized (sub-counties) government. The ability of farmers to make effective demands for advisory services, and implicitly therefore for government funds, will depend upon their ability to organize themselves in groups.

Perhaps, the most innovative intervention in the PMA is the Non-Sectoral Conditional Grant (NSCG), sometimes called the PMA grant, aimed at empowering local communities in planning and decision making. It is "non-sectoral" meaning that NSCG resources can be used on any sector seen as a priority unless those sectors are separately funded, as is the case with health and education. It is "conditional" in that it has to be used on poverty-reducing activities that benefit the community as a whole. Implementation of the NSCG started in June 2001 in 24 districts. The record of the PMA as a mechanism of poverty reduction is examined in Section 4. First, however, we consider the appropriateness of targeting agricultural modernization in order to reduce poverty. 


\section{TARGETING THE POOR THROUGH AGRICULTURAL MODERNIZATION}

(a) Ugandan agriculture in the context of adjustment.

The rationale of the adjustment programs Uganda has undertaken since 1987, and particularly since 1992, has been that economic growth, especially in the agricultural sector, would result from liberalization and privatization. The major adjustment reforms in the late 1980s and early 1990s directly affecting agriculture were the devaluation of the Uganda Shilling (Ush) in 1987 followed by liberalization of agricultural input and output prices and the dismantling of the commodity boards which had dominated trade in produce such as coffee and cotton. Other reforms which affected agriculture less directly, but still significantly, encompassed reform of the financial sector including the sale of the Uganda Commercial Bank, reform of the transport, education and health sectors and, as is discussed in Section 4, decentralization of government structures.

The responsiveness of agriculture to policy reform within structural adjustment programs is a matter of contention in Uganda, as in other African economies (Dijkstra and van Donge, 2001, Belshaw et al., 1999, Kasekende and Atingi-Ego, 1999, Gibbon et al., 1993). Annualized growth of 5-6 percent was recorded in the Ugandan national accounts during the 1990s (Appleton, 2001b) and agricultural sector performance over the same period has been generally positive, but unpicking the precise causal relationships in a country which has undergone rapid policy reforms whilst recovering from civil war and infrastructural breakdown is difficult. Belshaw et al., have argued that in Uganda "a significant feature of the decade since 1987 has been the slow or negligible recovery of these [agricultural] tradables" (1999: 674). In contrast, Dijkstra and van Donge (2001) contend that significant supply response and diversification into new agricultural sectors has resulted from market liberalization. In particular, export volumes of cotton and tobacco grew by $177 \%$ and $1542 \%$ respectively (Dijkstra and van Donge, 2001, Table 8), and sales of some non traditional exports, such as fish and fish products and also cut flowers, increased markedly also. There have also been increases in the export of crops such as maize, beans and legumes, although the significance of these exports has fluctuated over the 1990s (Balihuta and Sen, 2001).

Ugandan agricultural performance - and indeed economic performance more generally - is dominated, however, by coffee, the export of which grew little, in volume terms, between 1986/87 and 1997/98. Balihuta and Sen argued that farmers' earnings from coffee improved: "for coffee there has also been a sharp increase in real producer prices as a ratio of cost of production from $37 \%$ in 1989 to $194 \%$ in 1996 . The share of producer prices as a ratio of world prices has also steadily increased from $12 \%$ in 1987 to $79 \%$ in 1998" (2001: 7). However, these positive developments for coffee producers were subsequently undermined by declining prices (Figure 1), with the $1999 / 00$ price falling to $36 \%$ of what it was in 1994/95. The implications of this for the Ugandan economy as a whole (Figure 2) were a rapid deterioration in the trade balance between 1989 and 2000, so that the trade deficit in $1999 / 2000$ was almost four times greater than it was in 1991/92.

\section{[FIGURE 1 ABOUT HERE]}

[FIGURE 2 ABOUT HERE]

Overall, the balance of evidence is that since 1987 trends in production and exports of agricultural commodities have been upwards, and it is clear that the strategy of the Ugandan government regarding agriculture and poverty is based on a continuing significant growth in agricultural production and in the share of that production that is marketed. However, even for those who attribute significant supply response to liberalization, there is considerable doubt regarding the scope for further supply increases. Hence Dijkstra and van Donge argue that "the supply response to liberalization may have run its course. Slack capacity in the economy has 
been taken into production and further growth requires investments, which are often constrained by poverty at the level of the enterprise" (2001: 842).

\section{(b) Targeting poverty or production?}

If Dijkstra and van Donge are correct that the processes by which output and incomes increased during liberalization have to a large extent run their course then an evaluation of the PMA requires careful consideration of the targets identified. In operationalizing the PMA's mission of "eradicating poverty by transforming subsistence agriculture to commercial agriculture" (MAAIF and MFPED, 2000:27), some ambiguity is apparent, as a recent review of the PMA comments:

"The PMA document and the NAADS Master Document...do not disaggregate far on poverty grounds: both state that the largest group of farmers (70\% and $80 \%$ respectively) are 'subsistence farmers'...If rural poverty in Uganda is around $40 \%$, then not all of the 'subsistence' group are poor” (Ekwamu and Ashley, 2003:64).

Similarly, a review of the non-sectoral discretionary grant (NSCG), observed:

"The categorization of the poor in projects was not clearly defined. This was reflected even in work-plans of most sub-counties, where the beneficiaries are simply stated as communities or just farmers." (PMA, 2002:10).

This ambiguity of target' is manifest not only in relation to defining 'the poor' but also with respect to the 'private sector' that is to be instrumental in achieving poverty-reduction. Ekwamu and Ashley (2003:33) observe that while the 'private sector' mostly refers to commercial companies and traders, rather than farmers or NGOs, some involved in the PMA include within the private sector farmers, traders, NGOs, companies and individuals providing services, and the PMA document itself acknowledges that farmers are private sector operators. The possibility that 'farmers' are simultaneously identified as the targets of 'poverty reduction' through the PMA and as part of the 'private sector' through which this is to be achieved reflects a key contested aspect within the PMA: whether it is primarily about 'modernization' to achieve growth in agricultural production, with poverty reduction an assumed consequence, or whether it is primarily aimed at poverty reduction, that is, at the poor, with increased (marketed) production a logically associated outcome.

The 'modernization' element of the PMA mission draws on the analysis of Ugandan farming households as having achieved increases in output through increasing area cultivated, while productivity per unit area remained stagnant due to low levels of investment and modern technology use (Table 3), but, nonetheless, with high a propensity to sell their output if they have access to markets. Since, with the exception of those in the northern region, over 75 percent of Ugandan farming households sell part of their output (Table 3), the modernization goal of the PMA could more accurately be considered as increasing the share of marketed output from small-scale farmers.

[TABLE 3 NEAR HERE]

Reviews of the PMA (Ekwamu and Ashley, 2003; PMA, 2002) provide evidence that "a number of important actors" (Ekwamu and Ashley, 2003:29) at both national and local levels believe that the PMA should be focused not on the 40 percent of rural households below the poverty line, but on those better endowed with the resources of land and livestock to 'achieve results', as exemplified by these quotations of Ugandan members of parliament (Ekwamu and Ashley, 2003:49):

"Non-Sectoral Conditional Grants should be conditional grant to agriculture and should target small and medium size enterprises" 
"It is better to push a wheel-barrow of money than one with stones - you need to target the middle class as a means to uplift the poor."

Views in favor of modernization range from a local interest in securing a share of government (NSCG) funding to more ideological positions exemplified above, that propose that poverty reduction may occur through the development of markets, whether of agricultural goods or for labor, but it would be a secondary effect. These differences regarding the primacy of modernization or poverty reduction have important implications for how the PMA is implemented and these are discussed further in Section 4. It is important first to identify the nature of the obstacles confronting efforts to "eradicate poverty by transforming subsistence agriculture to commercial agriculture" (MAAIF and MFPED, 2000:27).

\section{(c) Transforming Ugandan agriculture}

The observation above that "further growth needs investments" (Dijkstra and van Donge, 2001:842) is particularly pertinent for Ugandan agriculture since the withdrawal of the state guarantee system of crop finance has meant that producers are forced to raise the necessary capital from within the household or from private lenders. As a result, the share of commercial bank loans made to agriculture fell as a percentage of total loans from $48 \%$ in 1988 to 20\% in 1996 (Balihuta and Sen, 2001). While government funding to commercial agriculture has been made available by the Strategic Export Initiative, and a recovery in largescale estate agriculture is being sought through foreign investment (see UPPAP, 2002: 72-9), the PMA is to assist poorer farmers through its financial services 'pillar' which establishes a legal framework for microfinance deposit-taking institutions (enacted by parliament in April 2003).

However, data of the kind presented in Table 4, showing poorer farmers with less land and fewer livestock assets, have led to suggestions (Ellis and Bahiigwa, 2003), that the PMA emphasis on agriculture productivity growth may be targeted at those least able to make use of it. Instead, it is suggested that more account needs to be taken of non-farm income as a route to improve incomes among the poorest.

\section{[TABLE 4 ABOUT HERE]}

This reflects growing interest in the role of non-farm income in rural livelihoods in recent years (Reardon, 1997, 1998; Barrett et al., 2001; Ellis, 2000; Bryceson, 1999, 2002; Start, 2001; Canagarajah et al., 2001). Evidence has accumulated that where financial services are poorly developed, and credit may be scarce, non-farm income is the main source of investment for raising farm productivity (Collier and Lal, 1986; Evans and Ngau, 1991, Reardon, 1998; Lanjouw and Lanjouw, 2001), and, where non-farm income could not be obtained locally, Africans have historically obtained it through migration (Adams, 1981; First, 1983; Tiffen and Mortimore, 1994; Low, 1986). Thus, in many parts of southern and West Africa, migration of younger men has for generations been an essential step in acquiring capital to establish themselves in farming.

Reardon's $(1997,1998)$ analysis highlights that the benefits of non-farm income are often quite unequally spread within rural communities, and those without access to migration or local non-farm income are likely to be at a severe disadvantage in terms of purchasing inputs, hiring labor, or investing in land- or labor-saving equipment (see Murton, 1999, on the case of terracing in Machakos, Kenya ). As a consequence "this will lead over time to an increasingly skewed distribution of land and other assets in rural Africa" (Reardon, 1997:743). There is evidence that this is the case in parts of Uganda. Figures 3-5 compare non-farm income shares and levels for different income levels in a recent study of 178 farms in four sub-counties in 
central and western Uganda (Bahiigwa et al., 2001). Figure 4 shows not only the disproportionately higher non-farm income earned by households in the higher income tercile, but also suggests that, where farm incomes are also much higher for wealthier households, the data for income shares (Figure 3) may mask the extent of the gap in value of income (Figure 4) between higher and lower income households.

[FIGURE 3 ABOUT HERE]

The data in Figure 3 are also compatible with a U-shaped relationship between total income and the share of the total derived from non-farm income (Lanjouw and Lanjouw 2001). This is explained by the distinction Barrett et al., (2001) make between the 'desperation-led' diversification of poorer households taking on agricultural laboring or low-value natural resource gathering for sale (fodder, firewood, wild foods, local trade), and the higher return diversification (furniture making, transport, longer distance trading, salaried employment) which is undertaken by better-off households and from which the poor are excluded by entry barriers of finance or education (see also Start, 2001). Thus, similar shares of non-farm income among the rich and poor translate into very much lower monetary value for poorer households than for wealthier. A similar observation has been made in relation to non-farm income generating projects in Uganda (Smith et al., 2001). In the Ugandan data presented in Figure 4, the disparity between upper and lower tercile income from non-farm sources can be attributed to the access of the upper tercile households to income from formal employment, which in rural areas of Uganda is chiefly derived from public sector jobs in teaching, health, and administration (see Figure 5).

\section{[FIGURE 4 ABOUT HERE]}

[FIGURE 5 ABOUT HERE]

These considerations suggest that strategies of poverty reduction that emphasize opportunities for non-farm income for the poor will only be effective if they can overcome current entry barriers to high-return sources of non-farm income. The most important entry barriers are those of capital and education. The latter implies that the government's implementation of universal primary education (UPE) will be of critical importance for medium and long term reductions in poverty. As suggested by Reardon (1997), in the longer run education may take over from land-owning as the main determinant of income.

However whilst the introduction of UPE in Uganda has been widely welcomed, certain aspects of its implementation have been observed to penalize the poor and this means that monitoring and adjustment is required as a matter of urgency to ensure that the poorest are not excluded or marginalized in the new system. For example, it has been documented that the pupils of the poorest families have been (illegally) excluded from school because they cannot afford uniforms and learning materials, and the lack of provision of school lunches, even for the poorest and orphans, increases the likelihood of absence or hunger-related inability to progress adequately (UPPAP, 2002). It is also reported that problems attributed to poorly trained and motivated teachers are most acute in rural areas. This could be addressed through greater monitoring, but also through greater incentives such as the provision of adequate housing for teachers in remote areas (UPPAP, 2002). It is important to note, in addition, that increased school attendance may have short term negative impacts on farm productivity, given the importance of children in the agricultural workforce in Uganda. Official statistics indicate, for example, that in Uganda $52 \%$ of unpaid household agricultural labor is done by children (UBOS, 2002).

Although much of the discourse of the PMA implies the modernization of 'subsistence' farmers into commercial producers, there is evidence that the poor are highly risk-averse and 
unwilling to act in 'entrepreneurial' ways (Start, 2001). In these circumstances Reardon (1998:32) suggests that the most effective way of reducing poverty through non-farm income would appear to be expanding the employment opportunities in rural areas through medium or large-scale agro-industry. However, the Uganda Participatory Poverty Assessment Programme has published studies of estate agriculture in Uganda that suggest illegal contractual conditions and working hours are widespread, trade union representation is ineffective, and "it should not be assumed that big investments in the estate sector are good for the development of Uganda and benefit poor people" (UPPAP, 2002: 57). It would appear, therefore, that for such employment opportunities to constitute a route to poverty-eradication, effective regulation of the estate sector would be required.

The discussion above suggests that 'diversification' of poverty eradication targets outside small-scale agriculture are not straightforward, nor do they promise immediate results. The precise sequencing of the increases in farm income and non-farm income that allow the process of moving out of poverty vary across individuals, locations and time. For some, it will be the accumulation of non farm income that allows investment in the farm which in turn boosts income further. However, for many of the very poorest subsistence farmers, low educational attainment means the non farm income opportunities accessible to them offer such a poor return, compounded by negative impacts on their ability to farm their own land, that a focus on agriculture as the means by which to begin the transition from extreme poverty seems appropriate.

In light of this discussion, it is reasonable to pose the question that if increasing production and the marketed output of the poorest 'subsistence farmers' is indeed the right target for PMA to achieve a reduction in poverty, is there a problem with the mechanism being employed to achieve it?

\section{DECENTRALIZATION: THE WRONG MECHANISM?}

(a) Uganda's decentralization 1986-97

In Uganda, while the degree of "ownership" of many of the country's reforms has been the subject of debate, decentralization, albeit in different guises, has featured in the NRM's political approach since its Ten Point Programme when it assumed power in 1986. A number of statutes preceded the new constitution of 1995 and the Local Government Act of 1997, all of which contained elements concerning decentralization. The Decentralization Secretariat (1993) identified several objectives in this process including the transfer of real power to the districts, the bringing of political and administrative control over services to the point at which they are delivered, freeing local managers from national government constraints, improving financial accountability by closing the gap between tax collection and service provision and achieving democracy involving people at all levels.

In practice the decentralization programme converted the existing resistance councils (RCs), established during the civil war and the NRM's accession to power, to Local Councils (LC) at the level of village (LC1), parish (LC2), subcounty (LC3), county (LC4) and District (LC5). Councillors at the LC1, LC3 and LC5 levels are directly elected by citizens within geographically-defined constituencies. Members of LC2 and LC4 are administrative units whose membership is determined by that of the 'council executive' of the LCs in the tier below (i.e. LC1 executive members select members for LC2, LC3 executive members form the LC4) (Francis and James, 2003). 
Although an important aim of decentralization is to increase local control of, and accountability for, generating revenue to pay for public services, locally-generated revenue is generally less than ten percent of the overall funds administered by the Ugandan local councils. The remainder consists of transfers from central to local government. Most of these (84 percent in 2000-01) are 'conditional grants' which must be spent on sectoral projects in support of PEAP. The bulk of conditional grants (CG) originate from HIPC and other debtrelief and budget-support funds that, together with Ugandan government resources, are transferred by central government to local government via the Poverty Action Fund begun in 1998-9. Transfers to local government also include 'unconditional grants' (UCG), the expenditure of which is decided by local councils.

Central-local transfers more than doubled from 1997-8 to 2000-01, when they totaled Ug Sh 512 billion (US\$300million). However, the UCG component fell from 24 percent to 15 percent over the same period (Francis and James, 2003). Management and disbursement of CG is administratively complex due to a multiplicity of separate transfers and stringent monitoring requirements to ensure expenditure complies with the conditionality of the grants, by sector and locality. Some have argued that the preponderance of conditional grants in local expenditure has reinforced central line-ministry control, with local government acting as little more than a transmission belt for centrally-determined investment programmes (Craig and Porter, 2002).

Conversely, however, there are relatively few reporting requirements regarding the use of the unconditional grants, most of which are spent on general administrative costs (Francis and James, 2003), or the use of locally-raised revenue. There is now considerable evidence (UPPAP, 2000, 2002; Francis and James, 2003;) that accountability for the expenditure of such funds is poor, and that, in certain respects, notably that of privatization of collection of local taxes, the action of local government bears particularly harshly upon the poor (Ellis and Bahiigwa, 2003).

This evidence calls into question one of the principle assumptions underlying policies of decentralization of government: that those in power will be more responsive to the needs of the poor when the poor are closer, and therefore more visible, to the seat of power. This was recognized by the most recent report of the Participatory Poverty Assessment Project:

"In the light of the findings presented..., it is evident that the decentralization process needs to be critically and urgently reviewed. .... The question is: How much is the decentralization process facilitating, and how much is it hindering the delivery of propoor programmes? And what should be done about this?"(UPPAP, 2002: 162)

\section{(b) Decentralization and Implementing the PMA}

The budget for PMA priority areas ('pillars') has been estimated at Ush 403 billion for the 2001-2 financial year (Ekwamu and Ashley, 2003: 46). Of this total, less than 10 percent was allocated directly to local government, 20 percent was allocated via the Poverty Action Fund, 30 percent through the Ministry of Agriculture, Animal Industry and Fisheries, and the remainder to other ministries. In their assessment of the seven 'pillars' of the PMA, Ekwamu and Ashley (2003: 8) state that it is "likely that all pillars will be operational in a year or so", but that with two exceptions, all activity so far has been at national policy or legislative level. The pillars with visibility at local level are rural infrastructure (primarily through road construction) and NAADS, and projects funded through the Non-Sectoral Conditional Grant (NSCG). 
The rural infrastructure activities accounted for 29.4 percent of the total PMA budget, but were also augmented by local government allocations of NSCG funds to road expenditure. The NAADS programme started in July 2001 in six districts (out of 56), and was extended to a further ten districts a year later. Plans to further extend the programme from 16 to 21 districts in 2003 were delayed by budget restrictions that limited the original Ush 19 billion NAADS budget allocation to Ush 13 billion (Ekwamu and Ashley, 2003). A key factor in funding further NAADS expansion is the future of 135 other existing programmes related to agricultural extension, with a total budget estimated at Ush437 billion. Reductions in duplication among these projects is expected to release funding for the further expansion of NAADS.

In Districts where NAADS is operating, the primary activity has been to establish farmers forums (14 at district-level and 95 at sub-county level), and to promote the formation and registration of farmers groups. By July 2003, some 2800 such groups, covering 35 percent of those identified as eligible, had been registered (Ekwamu and Ashley, 2003: 54). Little evaluation of the performance of these farmer groups has been undertaken, although farmer groups organized under the NAADS program have been compared favorably, in terms of their organization, commitment, and capacity to manage projects, to farmers groups in non-NAADS sub-counties (PMA, 2002: 4).

It is less clear how much development has been achieved in promoting private sector providers of agricultural advice, and it appears that much of the advice to farmers groups continues to be provided by existing government extension services. One result of this will be the continued invisibility of such services to the poorest, reflecting the tension between the modernization and poverty reduction emphases. This is illustrated in the most recent poverty assessment, which observed: "extension agents themselves noted that they are forced to select aboveaverage farmers to work with, because 'government emphasises results'." (UPPAP, 2002: 64).

This is, in part, due to slower than anticipated 'delayering' of government services to provide technical advisors for the private sector agencies envisaged under NAADS. A further constraint on progress in NAADS is that reform of the agricultural research organization (NARO) has not advanced beyond government approval of policy and drafting of legislation. As a consequence, agricultural research resources have yet to be refocused on the needs of poor farmers and, despite new initiatives in disseminating information on current market prices, there is little capacity to generate technical advice that departs from traditional extension 'messages' that focus on the use of purchased inputs.

A similar problem affects the operation of the Non-Sectoral Conditional Grant (NSCG), which has been available in 24 districts since the PMA was launched. The NSCG is funded through the Conditional Grant transfers from central to local government via the Poverty Action Fund (see above). As a discrete source of funds for PMA-relevant investment by local government, the NSCG is the most visible manifestation of the PMA at local level. The grant is 'conditional' in that it can only be used for investments that benefit the community (rather than specific individuals) and must conform to the PMA's criterion of reducing poverty. Evaluations of NSCG investments indicate that they have often failed to meet either criterion: "There remain many instances where the NSCG is being used unimaginatively for input distribution, leaving a feeling of 'business as usual"' (Ekwamu and Ashley, 2003:39). These issues are reflected in the first monitoring report on the NSCG (GOU, 2001), which, while viewing the majority of the investments surveyed as acceptable, concluded that only $50 \%$ qualified as strictly compliant with NSCG funding criteria, as summarized in table 5. 


\section{[TABLE 5 ABOUT HERE]}

Some of the projects implemented, such as construction of sub-county headquarters, were not PMA-compliant. Further, some of the projects falling within the acceptable investment areas (NSCG-compliant) were implemented in unacceptable ways. For example, many projects distributed free crop and livestock production inputs which is not PMA-compliant. Projects distributing inputs were reported in 23 of the 24 districts. Where on-farm multiplication of seeds and animal breeding were observed by the monitoring teams, it was not clear how the rest of the community members would benefit from these projects, making them look more like private goods (GOU, 2001). This first assessment concluded:

"Where assessments could be made, often it was the less poor members of a community who were potentially able to derive any benefits arising (e.g., by virtue of the location of a project, such as fish ponds or communal bulls being placed on the land of wealthier community members)" (GOU, 2001:22).

Further monitoring of NSCG projects in 21 districts in 2002 concluded that PMA guidelines on NSCG criteria for project funding had been noted and projects had a more 'public good' character. Ekwamu and Ashley (2003: 39), for example, identify cases in Arua district which show "strong synergism between NSCG and NAADS funds" and "coordinated action to use these funds (for) priorities identified by the local communities", and in Masaka "systematically identified PMA intervention areas and phased activities to target poverty and income generation". However, such cases appear to be the exception. The Participatory Poverty Assessment reported: "There was only one case of good accountability systems. This...comes from Ruhaama Sub-county that covers Kicece village, in Ntungamo. ...the District conducts regular audit exercises and ...(T)here is information on receipt and utilization of funds displayed on the Sub-county noticeboard (although Kicece residents were not aware of this) and regular receipt of the $25 \%$ of graduated tax in Kicece." (UPPAP, 2002:173). Moreover, those investments with wide 'community' benefits, such as roads, cattle dips, market infrastructure (slaughter slabs, market stalls, milk cooling plants), and farming demonstrations, were judged to have been less well-managed and to have provided less value for money than where the projects were for the benefit of "farmers groups or special interest groups" (PMA, 2002: 9). This last observation is consistent with the earlier monitoring reports and suggests that it is possible for local officials to interpret the 'community interest' stipulated by NSCG guidelines in various ways, including the provision of goods and services to quite a small number of beneficiaries, so long as these are constituted as a 'farmers group'.

Evaluations of the NSCG undertaken in 2003 do not differ greatly in their conclusions from those undertaken earlier, which concluded that awareness of both the PMA and NSCG were high among district and sub-county officials, but very low among community members. Most local government had met the minimum requirements such as opening an NSCG bank account but community participation in making decision on the use of NSCG was reported to be very low compared to the influence of political leaders and technical staff. It is this latter point that the review by Ekamwu and Ashley (2003: 39-40) highlights, not only in terms of the fact that it is effectively local government officials and local politicians who are selecting NSCG projects, thus violating principles of transparency and participation in the allocation of investment for 'the community', but also because these individuals are likely to identify the PMA and NSCG with increasing agricultural production, rather than with reducing poverty. Leaving aside questions of conflict of interest, it seems likely that the destination of NSCG funds allocated locally will be influenced by whether those making the decisions are aiming to 
boost aggregate agricultural production and income in the area or seeking to give priority to poverty reduction.

Other evaluations of the NSCG (PMA, 2002; UPPAP, 2002: 84-6) confirm that it is exceptional for decisions on NSCG funds to involve wider participation, with negative consequences for the impact of the projects on poverty. Information gathered in 30 sites across eight districts concluded:

"In just six sites in four districts some people reckoned to have benefited directly from the use of the grant. In four of these sites...community members reported that poor people did not benefit from the use of the grant. In three other sites, those responsible for decisions on or implementation of NSCG projects appeared to be of the view that the NSCG cannot or should not be used to benefit poor people, but should rather be used to assist those 'able to pay', 'manage' or 'achieve results'.'(UPPAP, 2002: 86).

\section{(c) The politics of poverty}

Concerns about the lack of 'pro-poor' priorities in allocation of NSCG funds by local officials and politicians reproduce the ambiguities regarding the PMA 'target' (modernization versus poverty reduction) discussed in Section 3. They are also consistent with the local politics of decentralized government that is emerging from recent studies of rural poverty in Uganda (Brock et al. 2003, Francis and James, 2003; UPPAP, 2002). These studies highlight the highly discriminatory local political environment which heightens the vulnerability of poorer social groups who include women, youth, displaced people, disabled people and ethnic minorities. These groups are not only excluded from representation and resources by formal barriers (e.g. land rights, requirements for the use of English in meetings), but also by informal social processes ('lobbying', social drinking) that largely determine the outcome of formal proceedings (Brock et al, 2003). It is unlikely that power relationships within such a political environment will channel resources to such groups and so reforms designed to assist the poor are likely to be managed for the benefit of the wealthy. The 'modernization' emphasis given to the PMA is one example, the reform of local taxation is another. Hence Ellis and Bahiigwa (2003) argue:

"The local tax regime now in place in Uganda is disabling in character, and likely to be more so in the future as it becomes more entrenched, and opportunities to exploit it for personal gain by insiders become better established over time......There is an evident disjuncture between the declared goals of PEAP and PMA .....and the emerging local tax regime." (Ellis and Bahiigwa, 2003: 1010-1011)

The regime to which they refer has arisen from the devolution of tax-raising powers to the local level as part of the process of fiscal decentralization. Rather than collect taxes directly, local authorities have contracted out tax collection to individuals, who tender for the right to collect tax in a particular locality. The result has been that virtually all financial transactions in rural Uganda are subject to taxation, and high cumulative rates of tax may be a disincentive to marketing agricultural goods, particularly for poorer producers. Furthermore it was found that 90-95 per cent of locally generated revenue in three districts surveyed was spent on sitting allowances for councillors.

Similar effects can be understood from observations by UPPAP (2002) on the operation of the 1998 Land Act: 
"In the sub-humid areas, communal grazing land, once freely available, has diminished since the passage of the 1998 Land Act and access to grazing areas is now determined by wealth. In Katebe in Rakai, Bubanda in Mubende and Kihagani in Masindi, the richer pastoralists have leased land and access to pasture and water has become a problem for the poorer pastoralists.'(UPPAP, 2002: 82).

This accumulation of evidence undermines some common assumptions about the positive effects of decentralization on rural development and poverty reduction, and bears out the importance of two related questions arising from experience with decentralization. These are, firstly, the extent to which the poor are able to bear the costs of political action to press their claims on local authorities, and, secondly, the potential of decentralization to simply empower local elites and perpetuate existing poverty and inequality (Johnson, 2001). Claims that democratic decentralization in rural areas will generate improvements in public accountability, environmental sustainability and the empowerment of poor and vulnerable groups (see Rondinelli et al., 1989, IFAD, 2001), must therefore be tempered by an acknowledgement that decentralization cannot, of itself, compensate for the absence of clear political commitment to poverty reduction by central government. Indeed, a comparative study of poverty-reduction effects of decentralization concluded: "the most successful cases were the ones where central government not only had an ideological commitment to pro-poor policies, but was prepared to engage actively with local politics....to challenge local elite resistance if necessary and to ensure full implementation." (Crook and Sverrisson, 2001: 48).

\section{CONCLUSION: IMPROVING POVERTY REDUCTION MECHANISMS}

This paper has examined the context of rural poverty in Uganda since 1987, and the PMA as a mechanism to reduce rural poverty through improving agricultural productivity and marketed output among poorer farming households. We have argued that poverty reduction - in terms of action that directly assists the poorest - is contested as a primary goal of the PMA by both national or central government actors, and local government officials and representatives, who favor investment in existing commercial, or less poor 'subsistence', farmers on the grounds that it offers a more secure prospect of achieving increased agricultural output and economic growth that will ultimately benefit the poor. The contested nature of the PMA goal, reflected in the ambiguous 'targeting' of some PMA policies, has allowed support through the NAADS and the NSCG to find its way to better off farmers rather than the poor.

An important question is whether the PMA can be made to 'work better' or whether the PMA framework needs to be re-thought. While it is clearly premature to judge the effectiveness of the PMA, since five of its seven pillars are at initial stages of implementation, the immediate efforts to generate results 'on the ground' through NAADS and NSCG do point to some lessons. The first of these is that PMA has perhaps been most effective in promoting a crosssectoral approach to poverty reduction at policy level, by providing a framework in which individual aspects of institutional reform (e.g. rural energy supply, road maintenance, agricultural research, and agricultural marketing) can be located and linked to one another using a common set of political criteria. If nothing else, the connectivity established in government policy-making is a positive outcome, despite cautions about the lack of 'buy-in' to implementation of the PMA priority areas on the part of some government ministries (Ekwamu and Ashley, 2003:11). This relative success at central policy-making level perhaps reflects the proximity of these activities to the PMA's chief poverty-reduction proponents within central government. 
This conclusion also suggests that PMA poverty-reduction objectives are most likely to be met if they can be delivered through ensuring that existing sectoral priorities, such as health services or Universal Primary Education, reach the poorest of rural households. This means that priority should be given to those problems associated with the reforms of the health and education systems most likely to affect the (rural) poor. The addition of agriculture as a specific item within the new school curriculum is to be welcomed. However problems regarding the exclusion of poorer school children because of their lack of schooling materials or uniform, the absence of school feeding programmes, and appropriate central and local monitoring and support for teachers in remote rural areas are critical issues.

The prospects for success for the PMA in achieving poverty reduction appear much less secure in relation to implementation of agricultural modernization through local agencies of decentralized government. It is here that ambiguity of targeting leaves open the possibility that outcomes will reflect local power structures rather than the priorities of the poor. The political contradictions of this situation are captured by two statements recorded side by side as 'weaknesses of the PMA' during a training course for civil society organizations in July 2002 (Ekwamu and Ashley, 2003:37):

"centralization of PMA. i.e. it's not yet strong in local government"

"Implementation is through corrupt decentralized government that is weak"

It seems inescapable that effective pro-poor intervention needs to first acknowledge fully the 'modernization' trajectory being pursued by wealthier agricultural interests, including the probability that this will involve increasing concentration of land holdings by larger farmers and increasing landlessness among the poor. This makes it clearer that modernization of agriculture is in fact a context for intervention to reduce poverty, and one which may not always be conducive to poverty reduction in the short term. It may be possible to improve targeting of NAADS through changing performance indicators: "NAADS performance targets need to be clear that getting support to poor farmers, including women, is the key result expected from extension agents, so that they do not target model farmers in order to 'get results'." (UPPAP, 2002:57). However, on the evidence reviewed in this paper, it is hard to see how NAADS will operate to reduce the disadvantages of the poor, rather than privileging the less poor on the grounds of their greater capacity to deliver results. If this is recognized, it is even possible that, shorn of the need to prioritize the poorest farmers, the NAADS framework of commercial supply of agricultural services will be able to operate on a more strictly commercial basis, so reducing the need for government funding. This may allow a retargeting of government resources to interventions with more unambiguous benefits to the poorest.

Such interventions on behalf of the poor will need to focus on reducing their vulnerability in this unfolding modernization process. In this context examining and learning lessons from those areas in which accountability has been relatively high and in which NSCG funds and other PMA initiatives have been targeted in accordance with national guidelines and the needs of the poorest in the locality would be appropriate.

The formation of farmers groups to improve representation of disadvantaged groups, such as women, youth, ethnic minorities and displaced people, will form part of this intervention, but other action that would combat sources of particular exploitation and disadvantage for the poor identified in this paper include the enforcement of labor legislation on agricultural estates, audits of local tax collection arrangements, and facilitating the exercise of land rights by the poor. The identification of such unambiguous intervention goals still leaves open the 
possibility that effective implementation will require central government agency, of a 'task force' type, unless or until appropriate political commitment to reducing poverty can be achieved at local level. It seems, however, that such centrally-driven efforts to reduce poverty need to be retained if the vulnerability of poorer groups is to be diminished - rather than increased - during Uganda's modernization.

\section{References}

Adams, A. (1981) The Senegal River Valley. In J.Heyer, P.Roberts, and G.Williams (Ed) Rural Development in Tropical Africa. London: Macmillan.

Appleton, Simon, (2001a) Poverty in Uganda, 1999/2000. Preliminary Estimates from the UNHS. Mimeo. Nottingham: University of Nottingham. UK

Appleton, Simon, (2001b). Poverty reduction during growth: the case of Uganda, 1992-2000. University of Nottingham. Mimeo. Nottingham: University of Nottingham. UK

Bahiigwa, G, Shinyekwa, I., Rigby, D., Woodhouse, P and Howlett, D (2001) Sustainability indicators for farming-based livelihoods in Uganda. Working Paper 8, Sustainability Indicators for Natural Resource Management and Policy. Manchester: Institute for Development Policy and Management, Manchester University, UK

Balihuta, A., and Sen., K (2001) Macroeconomic policies and rural livelihood diversification: an Ugandan case-study. LADDER Working Paper No.3. Norwich: University of East Anglia, UK

Barrett, C,. Reardon, T., and Webb, P. (2001) Nonfarm income diversification and household livelihood strategies in rural Africa: concepts, dynamics, and policy implications. Food Policy 26 (2001) 315-331.

Belshaw, D., Lawrence, P., and Hubbard, M. (1999) Agricultural Tradables and economic recovery in Uganda: the limitations of structural adjustment in Uganda. World Development, 27(4), 673-690.

Brock K, McGee R, Adong Okech R and Ssuuna J (2003) Poverty Knowledge and Policy Processes in Uganda: Case Studies from Bushenyi, Lira and Tororo Districts. Research Report 54. Brighton: Institute of Development Studies,

Bryceson., D (1999) African rural Labour, income diversification and livelihood approaches: a long-term development perspective. Review of African Political Economy. 80, 171-89.

Bryceson D (2002) The Scramble in Africa: Reorienting Rural Livelihoods. World Development. 30 (5): 725-739

Canagarajah S, Newman C and Bhattamishra R (2001) Non-farm income, gender, and inequality: evidence from rural Ghana and Uganda. Food Policy 26: 405-420

Collier P and Lal D (1986) Labor and Poverty in Kenya 1900-1980. Oxford: Clarendon Press. 
Craig, D and Porter D (2002) Poverty Reduction Strategy Papers: a new convergence. World Development 31(1): 53-69.

Crook, R and Sverrisson A (2001) Decentralisation and Poverty Alleviation in Developing Countries: a comparative analysis, or, is West Bengal unique? IDS Working Paper 130. Brighton: Institute of Development Studies.

Dijkstra, A and van Donge, J. (2001) What does the 'show case' show? Evidence of and lessons from adjustment in Uganda. World Development, 29(5), 841-863.

EPRC (2002). Costing the Millennium Development Goals. Uganda Country Study., Kampala: Economic Policy Research Centre..

Ekwamu A, and Ashley S (2003) Report on the Second Review of the Plan for Modernisation of Agriculture. Main Report (vol 2). Plan for Modernisation of Agriculture. Kampala: Ministry of Finance, Planning and Economic Development.

Ellis, F. (2000). Rural livelihoods and diversity in developing countries. Oxford: Oxford University Press.

Ellis, F and Bahiigwa, G (2001) Livelihoods and Rural Poverty Reduction in Uganda. World Development, Vol. 31, No. 6, pp. 997-1013.

Evans H and Ngau P (1991) Rural-urban relations, household income diversification and agricultural productivity. Development and Change 20, 519-545

First R (1983) Black Gold. Brighton: Harvester.

Francis, P and James R (2003) Balancing Rural Poverty Reduction and Citizen Participation: the contradictions of Uganda's Decentralisation Programme. World Development 31(2) 325337.

Gibbon P, Havenik K and Hermele K (1993) Uganda in P.Gibbon, P.Havenik and K.Hermele (Eds), A blighted harvest: the World Bank and African agriculture in the 1980s. London: James Currey.

GOU (2001). Report on the Non-Sectoral Conditional Grant Monitoring Exercise. PMA Secretariat, Entebbe: Ministry of Finance, Planning and Economic Development.

IFAD (2001) Rural poverty report 2001 - summary. Rome: International Fund for Agricultural Development.

Johnson., C (2001) Local democracy, democratic decentralisation and rural development: theories, challenges and options for policy. Development Policy Review. 19(4): 521-532.

Kasekende, L and Atingi-Ego, M (1999) Impact of liberalization on key markets in subSaharan Africa: the case of Uganda. Journal of International Development. 11(4): 411-436.

Lanjouw J and Lanjouw P (2001) The rural non-farm sector: issues and evidence from developing countries. Agricultural Economics 26, 1-23 
Low, A. (1986) Agricultural development in southern Africa. Farm household economics and the food crisis. Oxford: James Currey.

MAAIF and MFPED (2000). Plan for Modernization of Agriculture: Eradicating Poverty in Uganda. Kampala: Ministry of Agriculture, Animal Industry and Fisheries and Ministry of Finance, Planning and Economic Development.

MFPED (2000). Poverty Reduction Strategy Paper. Kampala: Ministry of Finance, Planning and Economic Development,.

MFPED (2001a). Poverty Eradication Action Plan (2001-2003) Volume 1. Kampala: Ministry of Finance, Planning and Economic Development, Uganda.

MFPED (2001b). Uganda Poverty Status Report 2001. Kampala: Ministry of Finance, Planning and Economic Development, Uganda.

Murton A (1999) Population growth and poverty in Machakos district, Kenya. Geographical Journal, 165 (1): 37-46.

PMA (2002) Report of the NSCG Post-monitoring meeting. 19 November 2002, Lweza. PMA Secretariat. Kampala: Ministry of Finance, Planning, and Economic Development.

Reardon, T. (1997). Using evidence of household income diversification to inform study of the rural non-farm labor market in Africa. World Development, 25(5), 735-747.

Reardon, T. (1998) Rural Non-Farm Income in Developing Countries. In: The State of Food and Agriculture 1998. Rome: Food and Agriculture Organization of the United Nations.

Rondinelli D, McCulough J, and Johnson R (1989) Analyzing Decentralization Policies in Developing Countries: a Political Economy Framework. Development and Change 20 (1): 5787

Smith, D., Gordon, A., Meadows, K., and Zwick, K. (2001) Livelihood diversification in Uganda: patterns and determinants of change across two rural districts. Food Policy 26: 421435.

Start, D (2001) The rise and fall of the rural non-farm economy: poverty impacts and policy options. Development Policy Review. 19(4): 491-505.

Tiffen, M., and Mortimore, M. (1994) More People, Less Erosion. Chichester: Wiley

UBOS (2002). Uganda National Household Survey 1999/00. Report on the Crop Survey Module. Entebbe: Uganda Bureau of Statistics,

UBOS (2003) Report on the Socio-Economic Survey, Uganda National Household Survey, 2002/03. Entebbe: Uganda Bureau of Statistics.

UPPAP (2000). Uganda Participatory Poverty Assessment Project Report. Kampala: Ministry of Finance, Planning and Economic Development, Uganda. 
UPPAP (2002). Uganda Participatory Poverty Assessment Project Second Report. Kampala: Ministry of Finance, Planning and Economic Development, Uganda.

Table 1. Changes in Rural Poverty Estimates* (per cent)

\begin{tabular}{l|llll} 
Region & $\mathbf{1 9 9 2}$ IHS & $\mathbf{1 9 9 7 / 9 8}$ MS-4 & $\begin{array}{l}\mathbf{1 9 9 9 / 2 0 0 0} \\
\text { UNHS }\end{array}$ & $\begin{array}{l}\mathbf{2 0 0 2 - 3} \\
\text { UNHS }\end{array}$ \\
\hline National rural & 59.7 & 48.7 & 37.4 & 41.7 \\
Central & 54.3 & 34.5 & 25.2 & 27.6 \\
East & 60.6 & 56.8 & 36.7 & 48.3 \\
West & 54.3 & 44.0 & 27.4 & 32.7 \\
North & 73.0 & 61.8 & 65.4 & 65.0 \\
Gini Coefficient & 0.324 & 0.311 & 0.332 & 0.363
\end{tabular}

Source: UBOS (2003: tables 6.3.2, 6.3.5)

IHS: $\quad$ Integrated Household Survey

MS -4: $\quad$ Fourth Monitoring Survey

UNHS: $\quad$ Uganda National Household Survey

*Poverty indicator: 'headcount' percentage of population living in households with real private consumption per adult equivalent below the poverty line for their region.

Table 2 Changes in consumption per adult Equivalent (1000 Ugandan Shillings, 1997) selected income deciles in urban and rural areas.

\begin{tabular}{|c|c|c|c|c|c|c|}
\hline Income Decile & Urban & & Rural & & Percen & \\
\hline Year & $99 / 00$ & $02 / 03$ & $99 / 00$ & $02 / 03$ & urban & rural \\
\hline 1 & 22.77 & 21.05 & 11.84 & 11.40 & -7.6 & -3.7 \\
\hline 2 & 30.79 & 28.18 & 15.43 & 14.62 & -8.5 & -5.2 \\
\hline 5 & 52.07 & 49.76 & 24.53 & 23.31 & -4.4 & -5.0 \\
\hline 8 & 99.52 & 94.76 & 39.19 & 38.21 & -4.8 & -2.5 \\
\hline 9 & 147.38 & 146.71 & 50.46 & 53.02 & -0.5 & 5.1 \\
\hline
\end{tabular}

Source: UBOS (2003: table 6.3.4) 
Table 3. Ugandan Farm Characteristics

\begin{tabular}{l|ccccc} 
& \multicolumn{5}{|c}{ Regions } \\
& Uganda & Central & East & North & West \\
\hline $\begin{array}{l}\text { \% HHs receiving government } \\
\text { extension advice (1998) }\end{array}$ & 11.4 & 9.5 & 12.7 & 10.9 & 11.9 \\
$\begin{array}{l}\text { \% HHs planting improved food } \\
\text { crop varieties (1998) }\end{array}$ & 10.2 & 11.3 & 16.7 & 8.6 & 3.6 \\
$\begin{array}{l}\text { \% HHs selling part of the } \\
\text { produce (1998) }\end{array}$ & 75.3 & 80.1 & 81.1 & 59.2 & 78.2 \\
$\begin{array}{l}\text { \% HHs using fertilizer } \\
\begin{array}{l}(1 \text { st season) } \\
\text { \% HHs using pesticides }\end{array}\end{array}$ & 2.5 & 2.6 & 2.3 & 4.4 & 1.3 \\
& 6.4 & 10.4 & 9.2 & 2.5 & 3.3
\end{tabular}

HHs: households

Source: UBOS (2002)

Table 4. Land and Livestock Assets by Income Tercile

\begin{tabular}{|c|c|c|c|c|}
\hline \multirow{2}{*}{ Sample (sub-county) } & \multicolumn{4}{|c|}{ Income Terciles } \\
\hline & $\mathrm{I}$ & II & III & Total \\
\hline Land Owned (ha) & & & & \\
\hline Bbaale & 3.1 & 15.9 & 44.3 & 21.1 \\
\hline Bubare & 14.6 & 28.4 & 52.8 & 31.5 \\
\hline Nazigo & 3.3 & 4.7 & 11.1 & 6.4 \\
\hline Nyakayojo & 2.3 & 12.6 & 11.1 & 8.6 \\
\hline All Districts & 2.8 & 9.3 & 35.8 & 21.9 \\
\hline Livestock CEUs & & & & \\
\hline Bbaale & 16.0 & 26.6 & 36.8 & 26.5 \\
\hline Bubare & 20.5 & 36.8 & 69.1 & 42.1 \\
\hline Nazigo & 1.8 & 2.8 & 8.5 & 4.3 \\
\hline Nyakayojo & 3.0 & 7.9 & 19.2 & 9.8 \\
\hline All Districts & 5.1 & 13.5 & 40.3 & 19.8 \\
\hline
\end{tabular}

Source : Bahiigwa et al., (2001) 
Table 5. NSCG Investment Compliance

\begin{tabular}{|c|c|c|c|}
\hline \multirow[t]{2}{*}{ Investment } & \multicolumn{2}{|c|}{$\begin{array}{l}\text { Districts reporting at } \\
\text { least one project }\end{array}$} & \multirow{2}{*}{$\begin{array}{c}\text { NSCG } \\
\text { Compliance }\end{array}$} \\
\hline & Number & Percent & \\
\hline Road improvement & 14 & 58 & * \\
\hline Provision of rural market infrastructure & 15 & 63 & $*$ \\
\hline Storage & 1 & 4 & \\
\hline $\begin{array}{l}\text { Crop and livestock pest and disease } \\
\text { control }\end{array}$ & 13 & 54 & \\
\hline Animal breeding & 13 & 54 & \\
\hline Animal traction & 3 & 13 & \\
\hline Fisheries & 8 & 33 & \\
\hline Input availability and use & 23 & 96 & \\
\hline Water for production & 4 & 17 & \\
\hline Environment & 17 & 71 & $*$ \\
\hline Land utilization & 2 & 8 & \\
\hline Functional adult literacy & 2 & 8 & $*$ \\
\hline School gardening & 3 & 13 & \\
\hline Sensitization on PMA & 4 & 17 & $*$ \\
\hline Farmer training & 23 & 96 & $*$ \\
\hline Group formation & 1 & 4 & \\
\hline Planning \& budgeting & 3 & 13 & $*$ \\
\hline Health education & 4 & 17 & \\
\hline
\end{tabular}

Source: GOU, 2001

* indicates that projects comply with NSCG funding criteria 
Figure 1

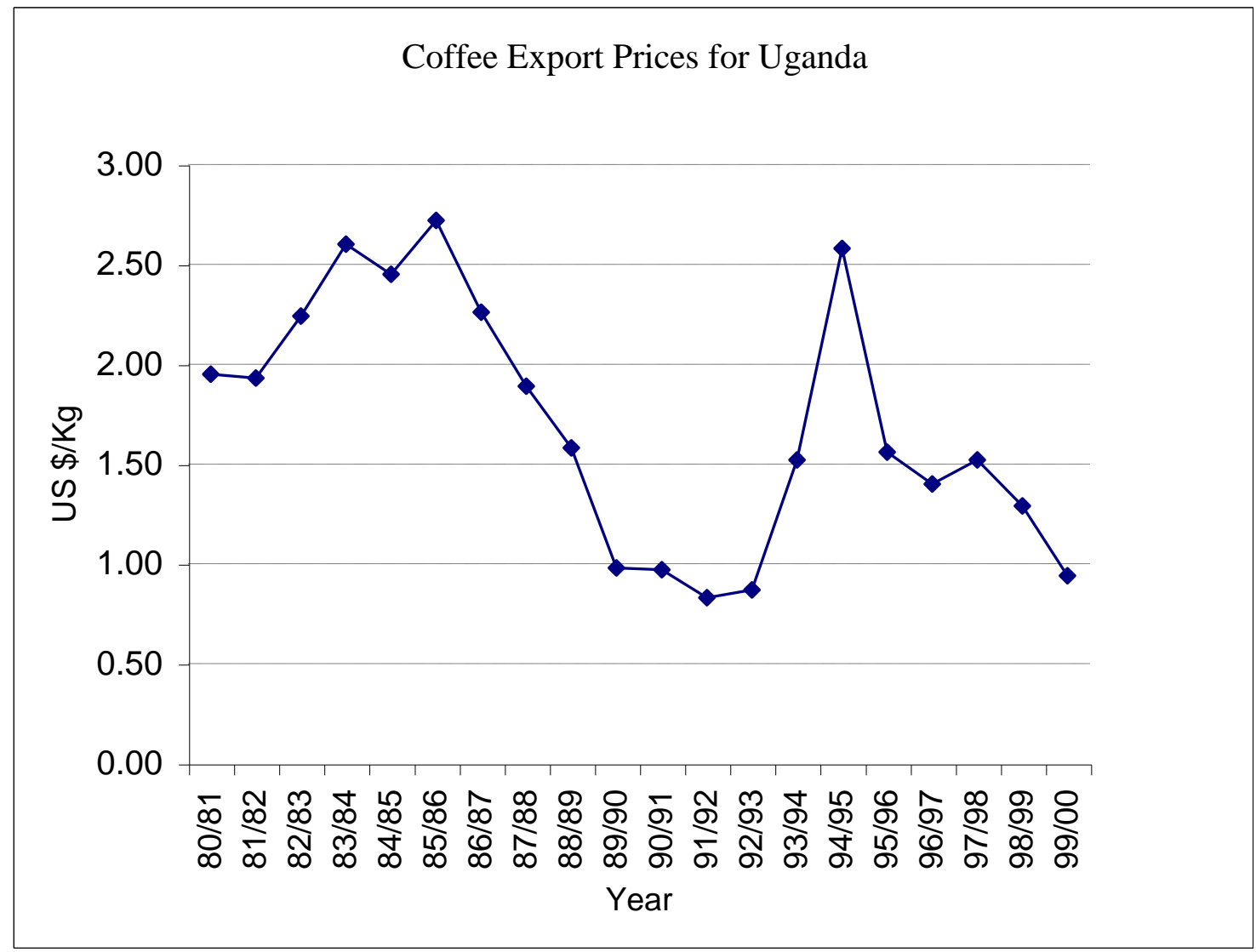

Source: Uganda Coffee Trade Federation (UCTF). The Coffee Year Book, 2000-2001

\section{Figure 2}

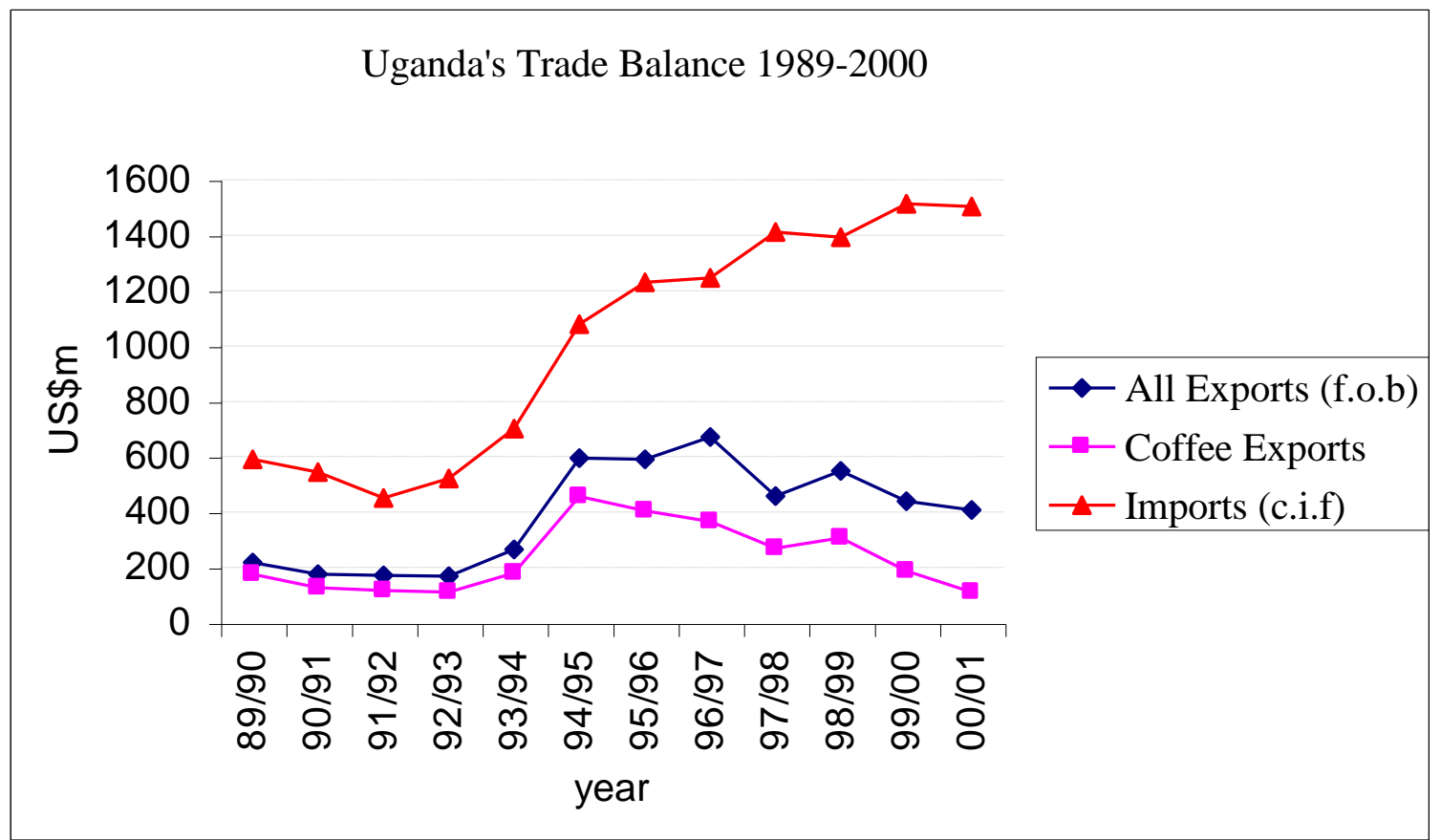

Source: Ministry of Finance, Planning and Economic Development (various years) 
Figure 3

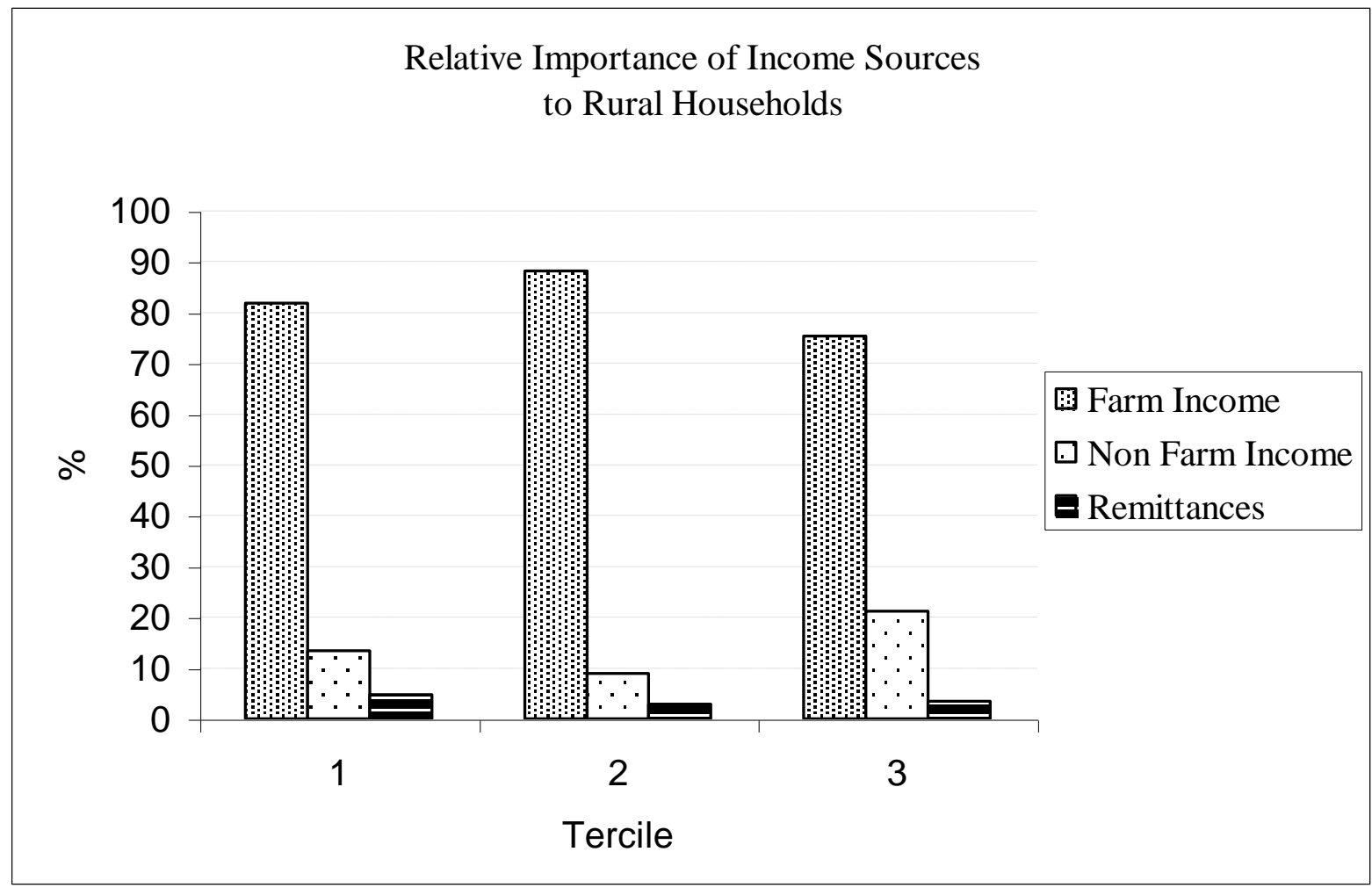

Source Bahiigwa et al., 2001

Figure 4

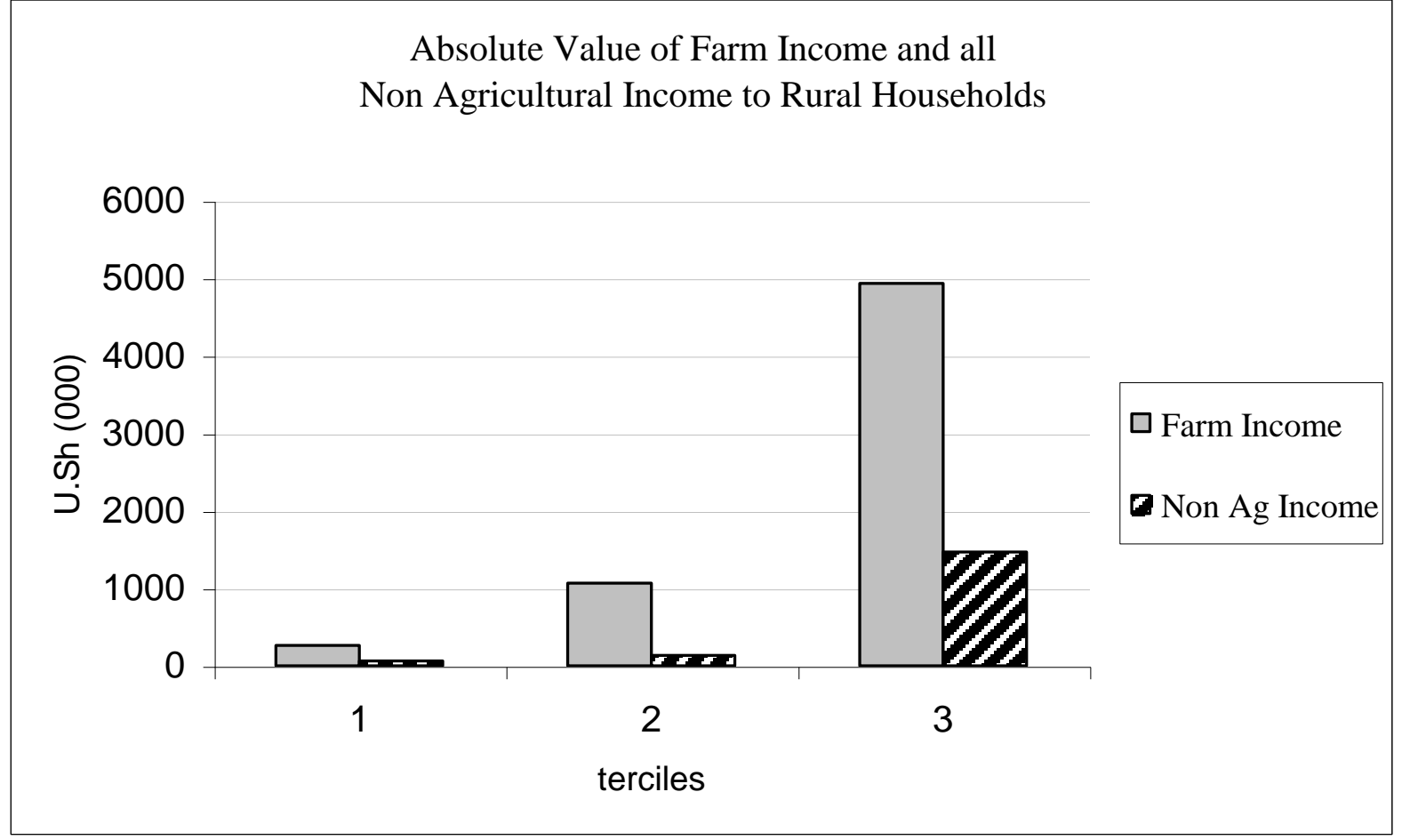

Note: Non agricultural income here is the sum of non farm income and remittance income Source Bahiigwa et al., 2001 
Figure 5

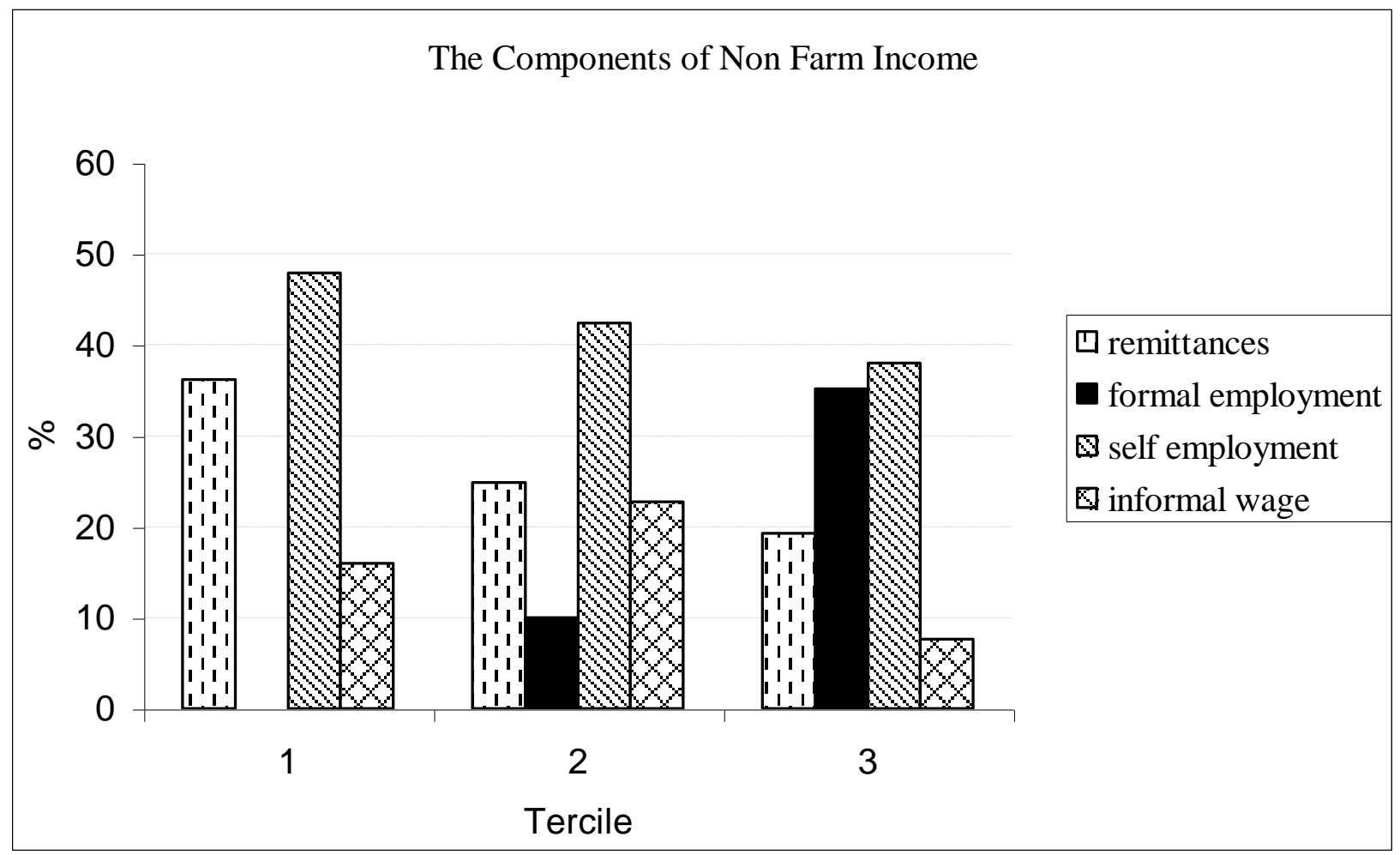

Source Bahiigwa et al., 2001 